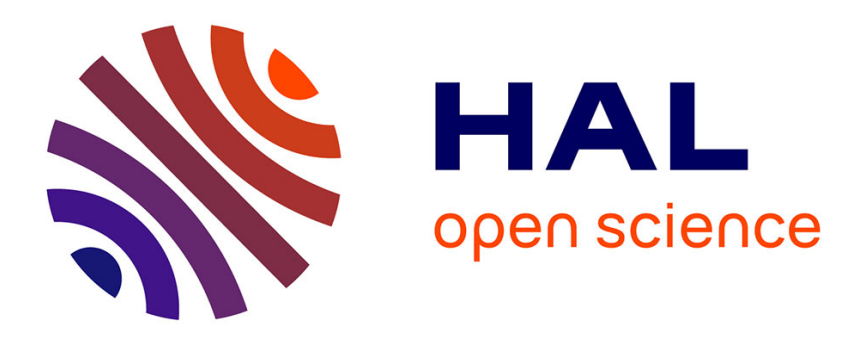

\title{
High pressure sensor for low temperature use
}

D. Fabre, M. M. Thiéry

\section{To cite this version:}

D. Fabre, M. M. Thiéry. High pressure sensor for low temperature use. Revue de Physique Appliquée, 1985, 20 (1), pp.45-47. 10.1051/rphysap:0198500200104500 . jpa-00245302

\section{HAL Id: jpa-00245302 https://hal.science/jpa-00245302}

Submitted on 1 Jan 1985

HAL is a multi-disciplinary open access archive for the deposit and dissemination of scientific research documents, whether they are published or not. The documents may come from teaching and research institutions in France or abroad, or from public or private research centers.
L'archive ouverte pluridisciplinaire HAL, est destinée au dépôt et à la diffusion de documents scientifiques de niveau recherche, publiés ou non, émanant des établissements d'enseignement et de recherche français ou étrangers, des laboratoires publics ou privés. 


\title{
High pressure sensor for low temperature use
}

\author{
D. Fabre and M. M. Thiéry \\ Laboratoire des Interactions Moléculaires et des Hautes Pressions, C.N.R.S., Université Paris-Nord, \\ rue J.-B. Clément, 93430 Villetaneuse, France
}

(Reçu le 24 avril 1984, révisé le 31 août, accepté le 20 septembre 1984)

\begin{abstract}
Résumé. - On a utilisé comme détecteur de pression, dans des expériences sous pression à basse température, un cristal de saphir dopé au titane. On observe le déplacement, vers le bleu, des deux raies de fluorescence correspondant à des transitions purement électroniques de l'ion $\mathrm{Ti}^{3+}$ en matrice de $\mathrm{Al}_{2} \mathrm{O}_{3}$. Ce déplacement, linéaire dans la gamme de pressions étudiée $(0-13 \mathrm{kbar})$, est de 7,9 et $7,8 \pm 0,3 \mathrm{~cm}^{-1} \mathrm{kbar}^{-1}$ à $4 \mathrm{~K}$ et de 8,5 et $8,4 \pm$ $0,2 \mathrm{~cm}^{-1} \mathrm{kbar}^{-1}$ à $77 \mathrm{~K}$.
\end{abstract}

\begin{abstract}
The fluorescence of a titanium doped sapphire crystal is used in low temperature experiments as a pressure sensor up to $13 \mathrm{kbar}$. With increasing pressure, the two zero phonon lines of the $\mathrm{Ti}^{3+}$ ion show a linear blue shift in the investigated pressure range. Details of the calibration measurements at $4.2 \mathrm{~K}$ and $77 \mathrm{~K}$ are presented. The pressure coefficients for the two lines are respectively 7.9 and $7.8 \pm 0.3 \mathrm{~cm}^{-1} \mathrm{kbar}^{-1}$ at $4 \mathrm{~K}$ and 8.5 and $8.4 \pm 0.2 \mathrm{~cm}^{-1} \mathrm{kbar}^{-1}$ at $77 \mathrm{~K}$.
\end{abstract}

\section{Introduction.}

Pressure is commonly determined in optical high pressure cells by measuring the pressure shift of the $R$ fluorescence lines of a ruby chip placed in the cell [1]. The pressure coefficient, was also determined at low temperature by Noack and Holzapfel [2] and in our laboratory [3]. At $4 \mathrm{~K}$, only the $\mathrm{R}_{1}$ line is observed : its pressure coefficient is $0.76 \pm 0.02 \mathrm{~cm}^{-1} \mathrm{kbar}^{-1}$ from (2) or $0.75 \pm 0.03 \mathrm{~cm}^{-1} \mathrm{kbar}^{-1}$ from our calibration. Due to its small width at $4 K$, the $R_{1}$ line frequency can be measured accurately; hence, a precision of about 200 bar could be expected in the pressure determination in our Raman experiments at $4 \mathrm{~K}$, carried out in a piston-cylinder type optical pressure cell up to $\sim 13 \mathrm{kbar}$. However, if reproducibility was good during the same experiment, that was not true for atmospheric pressure reference tests carried out after different experiments. The random shift of the 1 bar reference frequency is related to optical aberration errors and imperfectly controlled geometrical conditions, specially slight changes in the relative positions of the cell, the spectrometer and the frequency reference argon lamp; this shift is independent of the pressure and results in an additional incertitude of 5 or 600 bar, since one cannot be sure of mechanical reproducibility between the 1 bar pressure and the high pressure scans : indeed, releasing the pressure down to 1 bar implies, in our experimental conditions, a temperature increase for the decompression, the sample melting and the cell emptying before cooling back down to $4 \mathrm{~K}$; mechanical relaxation of the apparatus cannot be avoided during the course of this process.

The influence on a pressure measurement of the additional incertitude of $\pm 0.5 \mathrm{~cm}^{-1}$ will be reduced if the pressure sensor is a fluorescing material whose pressure coefficient is much higher than that of ruby (in absolute value); this is the case of the titanium doped sapphire. We first experimented its properties by observing, around $16200 \mathrm{~cm}^{-1}$, spurious bands in our Raman spectra; as a matter of fact, they were luminescence bands from the sapphire windows of the cell which contain chromium but also titanium impurities ; their blue shift due to pressure effect is by far higher than the corresponding red shift of the $R$ lines. Then we carried out a systematic study by introducing in the cell a titanium doped sapphire sample with $450 \mathrm{ppm}$ concentration. The two lines used, $T_{1}$ and $T_{2}$, around 16179 and $16217 \mathrm{~cm}^{-1}$ (i.e. around 6179 and $6165 \AA$ ) at 1 bar and $4 \mathrm{~K}$ (Fig. 1), occur on the high energy side of a broad and intense fluorescence band due to electronic transitions between the ${ }^{2} \mathrm{~T}_{2 \mathrm{~g}}$ ground state and the Jahn-Teller split ${ }^{2} \mathrm{E}_{\mathrm{g}}$ state of the $\mathrm{Ti}^{3+}$ ion in $\mathrm{Al}_{2} \mathrm{O}_{3}$. They correspond to the zero phonon transitions between the lowest vibrational state of ${ }^{2} \mathrm{E}_{\mathrm{g}}$, and 


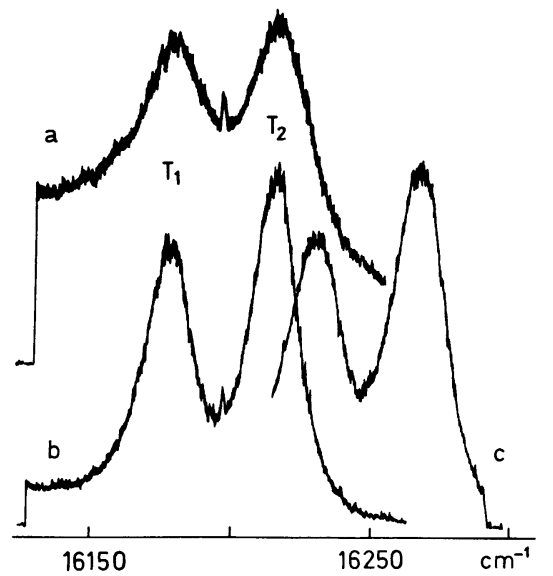

Fig. 1. - Typical spectra of titanium doped sapphire with $450 \mathrm{ppm}$ concentration. (Peak heights are arbitrary). Curve a : 1 bar ; $77 \mathrm{~K}$. Curve b : 1 bar ; $4.2 \mathrm{~K}$. Curve c : 7 kbar ; $4.2 \mathrm{~K}$. The small feature at $16197 \mathrm{~cm}^{-1}$ is a fluorescence line of the laser plasma.

respectively the $B_{3 / 2}$ or $E_{1 / 2}$ states of the ground state ${ }^{2} \mathrm{~T}_{2 \mathrm{~g}}$ [4]. At $4 \mathrm{~K}$, only the zero phonon state of the excited ${ }^{2} \mathrm{E}_{\mathrm{g}}$ state being populated, the two lines appear very clearly; they are still observed at $77 \mathrm{~K}$, but they are broader and superimposed on the increasing continuum background; they cannot be detected any more at room temperature. Therefore, their use is limited to low temperature experiments.

\section{Experimental procedure.}

The pressure dependence of the fluorescence $T$ lines was calibrated in our piston-cylinder type optical cell, from the applied load on the piston and by means of several pressure runs, according to the method originally developed by Bridgman to take into account the large frictions in the apparatus [5-8] : correction for friction is made by averaging horizontally between the curves for increasing and decreasing pressures. In order to provide hydrostatic pressure conditions, helium was taken as a pressure transmitting medium at 4.2 K (Fig. 2), [6-8] ; at $77 \mathrm{~K}$, pressure runs were made on argon (Fig. 3). The calibration curves, taken as the mean value of several runs, appear to be linear. Moreover, at $77 \mathrm{~K}$, for pressures lower than $4 \mathrm{kbar}$, the piston was not moved and a sample was pressurized with gaseous helium, resulting in a linear calibration curve (Fig. 3) of much better precision since the pressure was directly read on a calibrated manometer within \pm 10 bar. The sample luminescence was excited with either the blue or the green line of an argon ion laser.

\section{Results and discussion.}

The pressure coefficients of the $\mathrm{T}$ lines, at $4.2 \mathrm{~K}$ and $77 \mathrm{~K}$, obtained from the linear calibration curves are displayed in table $I$ and compared to the $R_{1}$ ruby

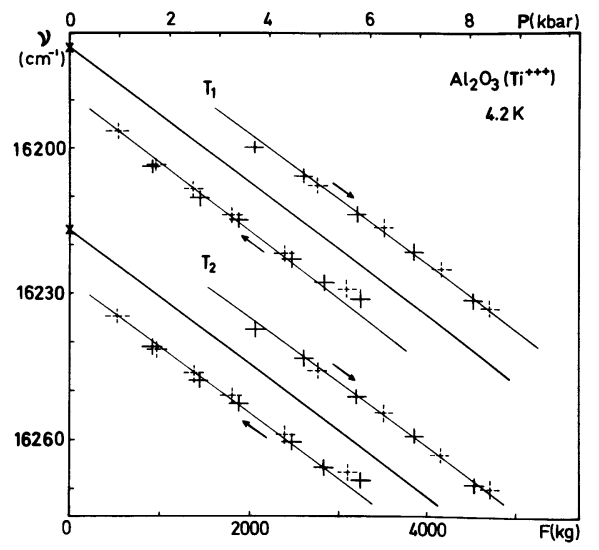

Fig. 2. - Frequency $v_{T}$ of the $T_{1}$ and $T_{2}$ lines as a function of the load $F$ applied on the piston for increasing (upper line of the cycle) and decreasing (lower line) pressures in solid $\mathrm{He}$ at $4.2 \mathrm{~K}$. The calibration curve (mean line) is related to the upper pressure scale. + --; two different pressure runs.

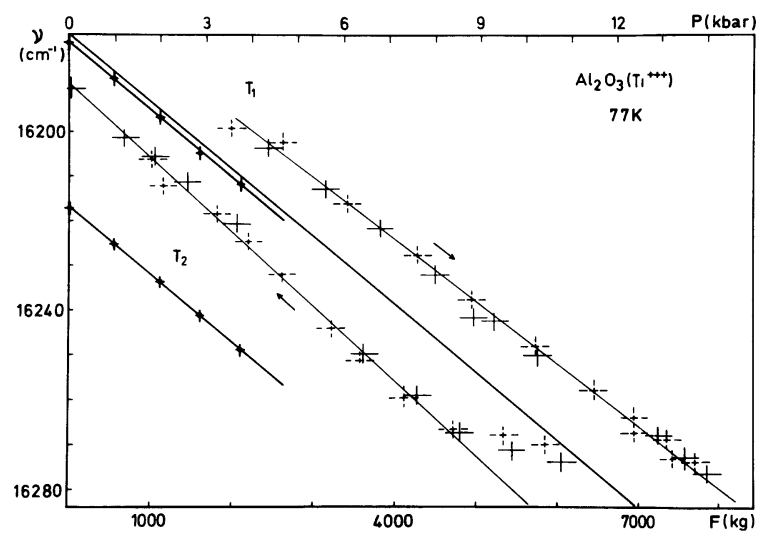

Fig. 3. - Pressure dependence of $\mathrm{Al}_{2} \mathrm{O}_{3}\left(\mathrm{Ti}^{3+}\right)$ fluorescence at $77 \mathrm{~K} . v_{\mathrm{T}_{1}}$ and $v_{\mathrm{T}_{2}}$ as a function of $\mathrm{He}$ gas pressure (upper scale). on the piston for two pressure cycles in argon. (cf. Fig. 2).

Table I. - Pressure coefficients of the $\mathrm{Ti}^{3+}$ ion $\mathrm{T}$ lines and of the ruby $\mathrm{R}_{1}$ line at $77 \mathrm{~K}$ and $4 \mathrm{~K}$.

\begin{tabular}{|c|c|c|c|c|}
\hline$T$ & \multicolumn{4}{|c|}{ dV/dp $\left(\mathrm{cm}^{-1} \mathrm{kbar}^{-1}\right)$} \\
\hline & $\mathrm{T}_{1}$ & $\mathrm{~T}_{2}$ & $\mathrm{R}_{1}{ }^{\mathrm{a}}$ & $\mathrm{R}_{1}{ }^{\mathrm{b}}$ \\
$77 \mathrm{~K}$ & $8.5 \pm 0.2$ & $8.4 \pm 0.2$ & - & $-0.76 \pm 0.02$ \\
& & & & \\
$4 \mathrm{~K}$ & $7.9 \pm 0.3$ & $7.8 \pm 0.3$ & $-0.75 \pm 0.03$ & $-0.76 \pm 0.02$ \\
\hline
\end{tabular}

$\left({ }^{a}\right)$ Our measurement.

(b) Reference [2]. 
coefficient obtained by the same method, $d v / d p\left(R_{1}\right)=$ $-0.75 \pm 0.03 \mathrm{~cm}^{-1} \mathrm{kbar}^{-1}$, at $4.2 \mathrm{~K}$. In spite of the inaccuracy related to the method in the case of large frictions this last result agrees reasonably with the value obtained by Noack and Holzapfel with a more precise method (2): $\mathrm{d} v / \mathrm{d} p\left(\mathbf{R}_{1}\right)=-0.76 \pm 0.02 \mathrm{~cm}^{-1}$ $\mathrm{kbar}^{-1}$ for $0<T<300 \mathrm{~K}$ (Table I).

The $T$ pressure coefficients are higher than the $R_{1}$ pressure coefficient by an order of magnitude. However, the $T$ lines are broader than the $R_{1}$ line. Advantages of using $T$ or $R_{1}$ lines can be compared according to their figure of merit $F$ defined as the ratio of the pressure coefficient to the line width of the line [1]. The apparent linewidths of the $T$ and $R$ lines, with the same $1.2 \mathrm{~cm}^{-1}$ slit widths, at $4 \mathrm{~K}$ and $7 \mathrm{kbar}$ for instance, are respectively about 24 and $2.2 \mathrm{~cm}^{-1}$, resulting in $F(\mathrm{~T}) \sim 0.32$ and $F(\mathrm{R}) \sim 0.34$. The figures of merit being close, the pressure determination could be made with the same precision in both cases, if reproducibility of mechanical and thermal conditions between the high pressure and zero pressure measurements is made sure. But, due to the possible drift of the wave number scale, independent of the sensor nature and of the pressure, it is advisable to use rather a titanium doped sapphire, specially at moderate pressures ; indeed, a frequency scale shift resulting in an additional error of 600 bar in the case of ruby, will produce an error of 60 bar only, if a titanium doped sensor is used ; in such a case, the time consuming and expensive 1 bar reference measurement can even be neglected in a pressure estimation. At $77 \mathrm{~K}$, lines broaden up; if the spectrometer slits can be kept narrow, $F(\mathrm{R})$ can be 30 percent higher than $F(\mathrm{~T})$. But for the same reason as stated above, it is still worth using the $\mathrm{T}$ lines.
The pressure dependence of the $\mathrm{Ti}^{3+}$ ion fluorescence was calibrated by using a crystal containing $450 \mathrm{ppm} \mathrm{Ti}$; clearly a better accuracy would be obtained by using a doped crystal with a weaker concentration since the $\mathrm{T}$ lines get then narrower. For instance, the $\mathrm{T}$ linewidths of a $10-20 \mathrm{ppm} \mathrm{Ti}$ doped crystal are about $4 \mathrm{~cm}^{-1}$ at $4 \mathrm{~K}$. However, independently of the lower intensity, a sensor with such a weak concentration cannot be used in an optical pressure cell with ordinary sapphire windows since they may contain themselves titanium impurities with similar concentration; the sensor fluorescence is then not clearly separated from the window fluorescence whose pressure dependence is not linear due to the complex strain conditions they experience $[6,7]$.

The fragments, with various geometries, of the crystal we used, give the same results (within the errors). Samples from other provenances may differ slightly by the 1 bar frequency according to the concentration or the growing process, but the pressure coefficient is probably a characteristic of the $\mathrm{Al}_{2} \mathrm{O}_{3}\left(\mathrm{Ti}^{3+}\right)$ material, as in the case of ruby.

We may conclude that at least up to $15 \mathrm{kbar}$ and at temperature lower than $80 \mathrm{~K}$, the titanium doped sapphire, $\mathrm{Al}_{2} \mathrm{O}_{3}\left(\mathrm{Ti}^{3+}\right)$, is a good pressure sensor. In a next step, it will be tested at higher pressures.

\section{Acknowledgments.}

We like to thank the "Société Criceram», filiale « Pechiney », (department « le rubis synthétique des Alpes ") for kindly providing us with titanium doped crystal samples.
[1] Barnett, J. D., Block, S. and Piermarini, G. J., Rev. Sci. Instrum. 44 (1973) 1.

[2] Noack, R. A. and Holzapfel, W. B., Proceedings of the Sixth AIRAPT International High Pressure Conference, edited by Timmerhaus, K. D. and Barber, M. S. (Plenum, New York) 1979.

[3] FABre, D. and ThiÉRY, M. M., unpublished.

[4] Gächter, B. F. and Koningstein, J. A., J. Chem. Phys. 60 (1974) 2003.
[5] Stewart, J. W., J. Phys. Chem. Solids 1 (1956) 146.

[6] Fabre, D., Thiéry, M. M. and Vodar, B., C.R. Hebd. Séan. Acad. Sci. Ser. B. 280 (1975) 781.

[7] Fabre, D., High Temp. High Pressure 8 (1976) 689.

[8] SwEnson, C. A., in Rare Gas solids, vol. II, edited by Klein, M. L. and Venables, J. A. (Academic Press, London) 1977, p. 835-842. 